
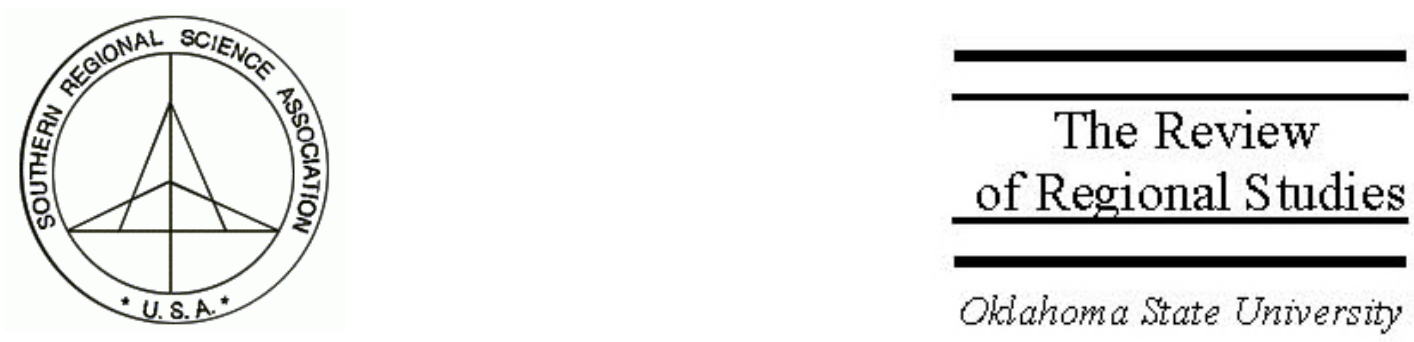

\title{
Fiscal Policy and Economic Growth: The Case of the Italian Regions
}

\author{
Monica Auteri \\ Dipartimento di Teoria Economica e Metodi Quantitativi, Università "La Sapienza," \\ Roma and Università degli Studi della Tuscia, via San Carlo s.n.c. - Viterbo - Italy, \\ email:mauteri@unitus.it \\ Mauro Costantini \\ Dipartimento di Teoria Economica e Metodi Quantitativi, Università “La Sapienza,” \\ Roma- Italy, email: mauro.costantini@uniroma1.it
}

\begin{abstract}
This paper seeks to contribute to our understanding of the relationship between economic policy and economic growth. With the use of a standard growth model, it assesses the influence of public investment and public transfers on the rate of economic growth. It does this by using data from the 20 Italian regions between 1970 and 1995. While the results show a positive influence of public investments on economic growth, this was not the case for public transfer payments in Italy.
\end{abstract}

Keywords: Growth; Fiscal policy; Regions

JEL classification: E62; O23; 040

The authors wish to thank the editor and two anonymous referees for helpful comments and Walter Inglese, Paolo Mattana, Beniamino Moro, and Richard Wagner for useful suggestions. Any errors that remain are, of course, the authors' responsibility. 


\section{INTRODUCTION}

The recent literature on economic growth has provided some insight into why countries grow at different rates over long periods of time. In some of these models, governmental choices regarding the share of government expenditure in output or the composition of expenditure and revenue can affect the long-run growth rate. The impact of fiscal policies on growth has been studied both in neoclassical growth models and in endogenous growth models (Rebelo 1991; Barro 1990; Jones, Manuelli, and Rossi 1993). According to the neoclassical growth models of Solow (1956) and Swan (1956), even if the government could influence the rate of population growth, for example by reducing infant mortality or encouraging child-bearing, this would not affect the longrun growth rate of per capita income. In these models, taxes and expenditures may influence the savings rate or the incentive to invest in physical or human capital; however, this would affect equilibrium factor ratios but not the steady-state growth rate. In endogenous growth models, by contrast, investment in human and physical capital can affect the steady-state growth rate, which gives more scope for tax and expenditure programs to influence growth. Since the pioneering contributions of Barro (1990), King and Rebelo (1990), and Lucas (1990), several papers have extended the analysis of taxation, public expenditure, and growth, demonstrating various conditions under which fiscal variables can affect long-run growth (see, for example, Jones, Manuelli, and Rossi 1993; Stokey and Rebelo 1995; Mendoza, Milesi-Ferretti, and Asea 1997). In an "AK" model, Rebelo (1991) shows that an increase in the income tax rate leads to a long-run decline in the rate of output growth. Barro (1990) and Jones et al. (1993) study optimal tax policies when government expenditure is a productive input and find a well-defined optimal tax rate. In a related context, Trostel (1993) finds a significant negative effect of income taxation on human capital. In all of these models, government tax policy is used to raise revenues.

The clarity of the models contrasts sharply with the murkiness of the evidence. Noting the lack of robust results in the empirical literature on the growth effect of fiscal variables, this paper aims to add to the body of empirical evidence by providing an investigation of Italian regions during the period 1970-1995. We offer a comparative analysis between the so-called "two Italies," the north and the center-south, to investigate the economic situation of the poorer part of the country, thereby adding a regional dimension to this literature.

A large and growing body of literature searches for the determinants of economic growth employing cross-country regression analysis (e.g., Barro 1990, 1991b, and 1992), Romer (1989a, 1989b, 1990a, and 1990b), Levine (1991), and Levine and Renelt (1992)). The cross-country regression approach implicitly assumes that the growth process possesses similar structural properties across the countries in the sample. Structural differences between countries, therefore, be they political, economic, social, or otherwise, do not condition the growth process. If they do, the effects are randomly distributed with zero mean. If structural differences between countries do matter 
significantly and non-randomly in the growth process, the existing cross-country research is potentially flawed. Attempts are sometimes made to control for such differences by including dummy variables for different regions of the world (e.g., dummy variables for African, Latin American, and other groups of countries). In our attempt to consider the effects, if any, of fiscal policies on growth, we use a panel data set to accommodate structural differences between regions and across time. We also compare the performance of the fixed and random-effect models.

The paper is structured as follows. Section 2 presents a critical review of both theoretical and empirical literature on the impact of different instruments of fiscal policy on economic growth. Section 3 outlines the building blocks of the model introducing the Bajo et al. (1999) growth model, which is the framework for the empirical analysis in this article. Section 4 derives several results about the use of fiscal policy to influence the growth path. The objective of Section 5 is to use the empirical findings to refocus analytical attention onto the effect of fiscal instruments on growth.

\section{FISCAL POLICY, GOVERNMENT SPENDING, AND GROWTH: A BRIEF SURVEY}

Economic growth was a central interest of Adam Smith and many of the classical economists of the nineteenth century. However, during the first half of the twentieth century, the topic fell out of vogue as microeconomic analysis increasingly came under the sway of equilibrium theory. With the Great Depression, macroeconomic analysis became obsessed with unemployment. After World War II, a number of economists became interested in economic growth; as a result, in the last half-century there have been three waves of interest in growth theory. The first was stimulated by the work of Harrod (1939 and 1948) and Domar (1946 and 1947). The question they posed, using somewhat different terminology, was under what circumstances is an economy capable of achieving steady-state growth? The second wave began in the mid-1950s with the development by Solow (1956) and Swan (1956) of a neo-classical model of economic growth. The original neoclassical growth models focused on the translation of saving into physical capital formation. The third wave was initiated in the mid-1980s by Romer (1986) and Lucas (1988). This wave centered on endogenous growth theories, which stressed both the apparent inconsistency between the implications of the neoclassical theory and the lack of evidence of convergence toward steady-state growth even among developed economies (Romer 1994) and the inability of the theory to successfully account for differences in income growth rates or income levels across countries (Romer 1994). A basic limitation of the neoclassical growth model is due to the assumption of diminishing returns to capital in the production function that led the model to predict that per capita output growth declines in the long run. A primary goal of the new growth theories is to build endogenous models where long-run growth rate of income is influenced by government policies such as fiscal policies, foreign trade policies, and population policies in addition to other variables (Srinivasan 1995). The 
intent is to challenge the neoclassical assumption that a policy can affect the level of economic activity but not the rate of economic growth.

Even more important than the results of their own research has been the stimulus that the Romer-Lucas work provided for a new burst of theoretical and empirical research in this field. This literature has been complemented by efforts to analyze the effects of the impact of fiscal policies and public infrastructure on national growth (see, for example, Barro 1991b; Rebelo 1991; Sala-i-Martin 1996; Levine and Renelt 1992; Easterly and Rebelo 1993).

However, it is easy to lose sight of the effect of fiscal settings on the long-run economic growth path. In fact, these effects are not insignificant and deserve careful investigation. The impact of fiscal policies on growth has been studied both in the neoclassical growth model (Kryzaniak 1967; Sato 1967) and in endogenous growth models (Rebelo 1991; Barro 1990; Jones, Manuelli, and Rossi 1993).

Robert Barro (1990 and 1991a) extended the constant returns to capital, or AK, growth model of Paul Romer (1986 and 1989) and Robert Lucas (1988) to include government-provided goods and services as productive inputs. In Barro's model, the long-run rate of growth depends on the share of output allocated to government purchases. With government inputs assumed to be productive, an increase in government purchases as a proportion of output increases the long-run growth rate. However, if government finances its purchases via an income tax, an increase in government purchases requires an increase in the income tax rate. This reduces the return to investment, so long-run growth slows. Barro shows that an increase in government purchases increases long-run growth if the ratio of government purchases to output is small, but slows growth for sufficiently large government purchases ratios.

Similarly, Shell (1967) and Grossman and Helpman (1991) consider models of technological progress in which government collects taxes and uses the proceeds to purchase goods and services, which are used in an R\&D process to create new knowledge. Since government goods generate technological progress, an increase in the government purchases ratio increases the long-run growth rate. Again, however, if government raises revenue via an income tax, increases in government purchases raise the income tax rate, so the return to investment and the long-run rate of growth fall. Grossman and Helpman found that an increase in government purchases increases long-run growth if the government purchases ratio is small, but decreases long-run growth when it is sufficiently large.

In an "AK" model, Rebelo (1991) shows that an increase in the income tax rate leads to a long-run decline in the growth rate of output. Barro (1990) and Jones, Manuelli, and Rossi (1993) study optimal tax policies when government expenditure is a productive input and find a well-defined optimal tax rate. In a related context, Trostel (1993) finds a significant negative effect of income taxation on human capital. In all of these models, government tax policy is used to raise revenues. 
The relationship between taxes and economic growth has been investigated by a number of economists over the years, and the evidence has not conclusively found that high taxes discourage economic growth. One of the reasons of the lack of a clear relationship between taxes and growth is that some things that tax revenue is used to pay for, such as education, transportation infrastructure, and the protection of property rights, have been found to stimulate economic growth. Hence, econometric studies could very well find that higher taxes are positively correlated with higher growth as governments spend their tax revenues efficiently. In a recent article, Padovano and Galli (2001) looked at marginal tax rates rather than average tax rates, as done in most previous studies. Including in their analysis measures of average fiscal pressure, they found that marginal tax rates turn out to be negatively correlated with economic growth. ${ }^{1}$

The implications of these results are several. First of all, Padovano and Galli (2001) essentially confirm that the level of taxation is not the real issue. ${ }^{2}$ But the finding that the marginal rate of taxation is negatively correlated with economic growth also makes sense because, ceteris paribus, the marginal tax rate acts as a disincentive to produce and generate income. Padovano and Galli's findings clearly reflect incentives better than did earlier studies of taxation and growth. They also seem to pose a dilemma: how can government collect enough taxes to perform all the needed tasks and yet maintain low marginal rates of taxation? The answer is not difficult if we take into consideration Anne Krueger's application of comparative advantage to government. The limitations to what government can do efficiently will probably tend to keep the overall need for tax revenue to a level where the marginal rates do not need to be very high either, even if taxes progressively place a higher burden on higher incomes.

The theoretical aspects of the role of productive government expenditure have been studied in Ramsey type economies by other authors, beginning with Arrow and Kurz (1970) and more recently by Aschauer (1988), Baxter and King (1993), and Turnovsky and Fisher (1995). This issue has also begun to be studied in an endogenous growth context by such authors as Futugami, Morita, and Shibata (1993), Turnovsky (1996),

\footnotetext{
${ }^{1}$ Where most studies have taken the ratio of total tax revenue to GDP as an explanatory variable in the usual growth regressions, Padovano and Galli (2001) carefully calculate the marginal tax rates and examine how they affect countries' rates of economic growth. They conclude their article as follows: "Our analysis of a cross-section time-series panel of 23 OECD countries for the 1950s-1980s decades show that high marginal tax rates and tax progressivity are negatively correlated with long-run economic growth. This finding contrasts the previous empirical literature, which concludes that there is no significant correlation between taxation and economic growth. We provide evidence that these results are due to a misspecification of the tax variables, which relied on average rather than marginal measures of fiscal pressure. In our model, when included with measures of average fiscal pressure, marginal tax rates turn out to be negatively correlated with the dependent variable (economic growth), while the other fiscal regressors show no significant correlation." ( Padovano and Galli, 2001, p. 50).

${ }^{2}$ High levels of taxation are compatible with both slow economic growth and rapid economic growth. It undoubtedly comes down to how well the tax revenue is spent.
} 
and Aschauer (1988). Futugami, Morita, and Shibata and Turnovsky, for instance, found that government financial policy has long-run macro effects, while Aschauer stressed the role of public investment as a factor enhancing private capital productivity.

We may find different analyses on the differential impacts of various types of government spending on long-run growth. For example, Barro's (1991a) empirical analysis differentiates productive government purchases, government consumption purchases, and transfer payments. Devarajan, Swaroop, and Zou (1996) distinguish different types of government purchases according to their marginal impact on private sector productivity. Miller and Russek (1997a, 1997b), in their empirical analysis, distinguish not only among different types of government purchases, but also between the use of taxes and borrowing to finance them. A large empirical literature, pioneered by Landau (1983) and Kormendi and Meguire (1985) and surveyed by Barro (1990) and Barro and Sala-i-Martin (1995), has tried to measure the impact of government purchases on long-run growth. We focus our empirical investigation on government transfer to local governments. Recent studies such as Sala-I-Martin (1996) found that public transfers are productive in that they raise the marginal product of private capital. However we found an inverse relationship in our empirical test due to the fact that transfers are not used to raise marginal product of private capital, especially in the south of Italy.

Furthermore, the relationship between redistributive policies and growth is the subject of a growing literature. Alesina and Rodrik (1994) discuss a model in which income distribution and redistributive politics affect growth and conclude that there is a negative effect of a greater inequality in income distribution on the growth rate. Several other articles have reached a similar conclusion. Benabou (1996) provides an extensive survey of recent studies of the connection between inequality, redistributive policies, and growth.

Although most researchers focused on the sources of growth across countries, recent studies such as Barro and Sala-i-Martin (1992), Razzolini and Shughart (1997), and Jayaratne and Strahan (1996) sought to explain variation in economic growth among U.S. states. They found support for the hypothesis that real per capita income between states converged. ${ }^{3}$ Following Armstrong and Vickerman (1995, p. 19), we believe that "perhaps the greatest methodological challenge of all is to adapt the concepts and techniques of new growth theory to a regional context." As yet, there have been only

\footnotetext{
${ }^{3}$ Barro and Sala-i-Martin (1992) estimated a model with cross-section data that related income growth to initial income and the sectoral composition of income in each state. Razzolini and Shughart (1997), using a considerably different model pooling cross-section and time series data, focused on the effects of state-level fiscal policies. They find that government size and, to a lesser extent, deficit financing produce negative and significant effects on economic growth. Jayaratne and Strahan (1996) also pooled cross-section and time-series data to test for the growth effects of institutional arrangements concerning banking. They found evidence that the removal of restrictions on branch banking positively and significantly increased state-level economic growth during the time period covered by their analysis.
} 
few explicit attempts to formulate regional endogenous growth models (Benabou 1993, 1994; Bertola 1993; Cheshire and Carbonaro 1995; Sala-i-Martin 1996).

Assuming that economic growth is desirable for its own sake, our aim in this paper is to explore whether state policy can influence the rate of growth of one or more regions within a nation, the south of Italy in particular. Re-examining some of the abovementioned hypotheses, we empirically test a model that assess the effect of government fiscal policies on economic growth in order to add to the debate on regional growth and inequality in Italy.

\section{THE ANALYTICAL FRAMEWORK}

In order to study the link between fiscal policy and the rate of growth in Italy, we use the model developed by Bajo, Carmen, and Montavez (1999) to empirically investigate the effects of fiscal policies on economic growth for the case of Spanish regions. The Spanish case offers important similarities with the Italian case. In Spain as in Italy there are both autonomous and ordinary regions. In Spain there exists a territorial organization of the state that permits the institutional structure of government to vary across regions. To some degree, this is also the case of Italy, where there are four layers of government: state, regions, provinces, and municipalities. The fiscal power of regional governments and the framework for intergovernmental relationships are framed by the Constitution and by ordinary legislation designed to implement constitutional principles. The Italian Constitution defines two different models of fiscal relations between regional and central governments. The first is related to the Regioni a Statuto Ordinario, the second to the Regioni a Statuto Speciale. ${ }^{4}$ The set of decentralized governments includes 15 regions with ordinary statutes (OSR); five regions with special statutes (SSR), ${ }^{5}$ one of which (Trentino-Alto Adige) is divided into two Provinces, each with its own special statutes; 102 provinces with ordinary statutes; and 8,100 municipal governments (Comuni). Regions with special statutes by constitution and successive constitutional legislation have a wider spectrum of public functions to perform than the other 15 regions (OSR).

Another interesting parallel may be found in the devolution process that, with different degrees characterizes both countries. In Spain as in Italy, special regions have legislative freedom (within the framework of the basic central legislation). In addition to the similarities in the distribution of powers between the different levels of government, there are also some common aspects of the distribution of resources at the regional level in the two countries. The annual flow of resources and public expenditures at the regional level comes mainly from financial transfers from the central government. In addition, the northern regions in both countries show an above-average concentration of

\footnotetext{
${ }^{4}$ Regions differ very much in population, size, and per-capita income.

${ }^{5}$ The Special Statute Regions are Sicilia, Trentino-Alto Adige, Valle d'Aosta, Sardegna, and Friuli Venezia Giulia.
} 
infrastructure and funds, which reflects the historical pattern of industrialization, while the southern regions have been traditionally agricultural.

Given the similarities that characterize the two countries, we believe that the model developed by Bajo, Carmen, and Montavez (1999) for Spain is well suited to investigate the Italian appearance. It is noteworthy that only public spending variables are taken into account in the model. In fact up to the end of the 1990s OSRs had basically no fiscal autonomy. Up to 95 percent of total expenditures were financed by central government grants to regional governments. The focus here is therefore on the amount of resources that are transferred to the regional budget in order to achieve a more equalized distribution of revenues. ${ }^{6}$

The Bajo, Carmen, and Montavez (1999) model (hereafter BDM model) emphasizes the role of fiscal policies in influencing the rate of economic growth, with government spending directly affecting private production functions. While public services are included as a productive input the BDM model departs from Barro (1990) in that it follows Cashin (1995) in including such private inputs as labor, physical capital, and human capital along with such fiscal policy instruments as transfer payments into private production functions.

In the traditional neoclassical growth model, the revenue raised from taxation is used to finance the provision of goods that neither enter into firms' production function nor affect the marginal utilities of agents' consumption (Feldstein 1974; Judd 1985). In contrast, the BDM model assumes that government spending is productive and does so through treating public transfer payments as inputs into private production that raise the marginal product of private capital by "improving the enforcement of private property rights in the economy, and by inducing relative unproductive agents to leave the labor force" (Cashin 1995, p. 239).

We study an economy in which the government raises taxes to finance its expenditures, and these expenditures may be directed to enhancing the productive activities of the economy. In this respect, the government expenditures will have a direct impact on production conditions and enhance the productivity of the existing

${ }^{6}$ During this last decade, there have been several attempts to increase the fiscal autonomy of OSRs. We can single out two phases in the reform process. In the first phase, the central government introduced the essential instruments for fiscal autonomy through the devolution of relevant taxes to the OSRs. The Regions received the yield of the health pay-roll tax, levied on salaries and self-employed incomes. As a consequence, the share of total expenditures financed by transfers dropped to 48 percent. In 1998 the health payroll tax and some minor regional taxes were abolished and replaced by a new tax, named Irap (Imposta regionale sulle attività produttive - Regional Business Tax), and by a regional surcharge ( 0.5 percent) on the personal income tax named Irpef (Imposta sul reddito delle persone fisiche). However the radical reform of the intergovernmental fiscal relations with reference to regional finance will not be taken into account in this paper given that the theoretical implication of the model are tested with a dataset from 1970 to 1995 , when OSRs had basically no fiscal autonomy 
capital stock. This effect, as previously underlined, has received increasing attention in the literature, both with respect to its empirical relevance and its theoretical consequences.

The economy production function in the BDM model is assumed to be:

$$
Y=K^{\alpha} H^{\beta}(A L)^{1-\alpha-\beta}\left(\frac{K G}{K}\right)^{\gamma}\left(\frac{T R}{K}\right)^{\theta}
$$

where $Y$ denotes output; $K, H$, and $L$ are the private inputs physical capital, human capital, and labor, respectively; $A$ is a labor-augmenting factor. In addition, $K G$ and $T R$ are defined to be the government-provided inputs public physical capital (KG) and transfer payments (TR). Borrowing from Barro and Sala-i-Martin (1992b), the BDM model introduces a more realistic possibility of congestion in the consumption of publicly provided goods (both physical capital and transfer payments) by individual household-producers (firms), because here (as is the case for a substantial share of government productive expenditures) public goods are rivals but not excludable. ${ }^{7}$ In the production function above, it is assumed that $\alpha>\gamma+\theta$, where $\gamma>0$ and, according to Sala-i-Martin (1996 and 1997), $\theta>0$; otherwise (e.g., if higher transfer payments would discourage growth incentives) the value of the externality would be negative so that $\theta<0$.

Defining $y$ as the level of output per effective unit of labor, $y=\frac{Y}{A L}$, and $k$ as the stock of capital per effective unit of labor, $k=\frac{K}{A L}$, the production function becomes:

$$
y=k^{\alpha} h^{\beta}\left(\frac{K G}{K}\right)^{\gamma}\left(\frac{T R}{K}\right)^{\theta}
$$

Notice that production function (2) exhibits decreasing returns to scale in all private inputs for a given state of congestion in the use of public capital and transfers. The degree of return to scale is ambiguous when all factors (i.e., $k, h, K G / K$, and $T R / K$ ) are taken together.

\footnotetext{
${ }^{7}$ This is the nature of the congestion existing in the consumption of public capital. It can represent, for example, the miles of highways provided, the number and size of airports, and law and order. Barro and Sala-i-Martin (1992b) argue that national defense and domestic security services (police and prisons), which are often deemed to be prototypical nonrival and nonexcludable public goods, can also be considered to be subject to a form of congestion, using the argument set forward by Thompson (1974).
} 
Next, the accumulation equations of the human $(\dot{H})$, physical $(\dot{K})$, and public capital $(\dot{K} G)$ are taken into account.

$$
\dot{K}=s_{K} Y-\delta K
$$

$$
\dot{H}=s_{H} Y-\delta H
$$

$$
\dot{K} G=s_{K G} Y-\delta K G
$$

where $\delta$ is the depreciation rate and is assumed to be the same for the three inputs under consideration, ${ }^{8}$ and $S_{K}, S_{H}$, and $S_{K G}$ are the output share of gross investment on private physical capital, human capital, and public capital, respectively.

Using $n$ as the rate of population growth and $g_{A}$ as the rate of technical progress, the following equations determine the rate of change in the previously considered factors.

$$
g_{k}=\frac{\dot{K}}{K}-g_{A}-n
$$

$$
\begin{aligned}
& \text { (7) } g_{h}=\frac{\dot{H}}{H}-g_{A}-n \\
& \text { (8) } g_{k g}=\frac{\dot{K} G}{K G}-g_{A}-n
\end{aligned}
$$

By equating $g_{K}, g_{H}$, and $g_{K G}$ to zero, the steady-state values, symbolized with an asterisk, are determined as follows.

$$
\begin{aligned}
& k^{*}=\left(\frac{s_{K}^{1-\beta-\gamma-\vartheta} S_{H}^{\beta} s_{K G}^{\gamma} s_{T R}^{\vartheta}}{\left(g_{A}+n+\delta\right)^{1-\vartheta}}\right)^{\frac{1}{1-\alpha-\beta}} \\
& h^{*}=\left(\frac{s_{K}^{\alpha-\gamma-\vartheta} s_{H}^{1-\alpha} s_{K G}^{\gamma} s_{T R}^{\vartheta}}{\left(g_{A}+n+\delta\right)^{1-\vartheta}}\right)^{\frac{1}{1-\alpha-\beta}}
\end{aligned}
$$

\footnotetext{
${ }^{8}$ The dot over a variable denotes it is time derivative.
} 


$$
k g^{*}=\left(\frac{s_{K}^{\alpha-\gamma-\vartheta} S_{H}^{\beta} s_{K G}^{1-\alpha-\beta+\gamma} s_{T R}^{\vartheta}}{\left(g_{A}+n+\delta\right)^{1-\vartheta}}\right)^{\frac{1}{1-\alpha-\beta}}
$$

Using $S_{T R}$ to denote the output share of government transfers, it is assumed that:

(12) $t r^{*}=\frac{S_{T R} y^{*}}{A}$

$$
A_{t}=A_{0} e^{g_{A} t}
$$

where $A_{0}$ is the initial value of the technological parameter $A$ and $t$ denotes time. Replacing these in equation (2), the (log of) the steady-state output per effective unit of labor $(\log y *)$ is obtained.

$$
\begin{aligned}
\log y^{*} & =\log A_{0}+g_{A} t-\frac{\alpha+\beta-\theta}{1-\alpha-\beta} \log \left(\delta+g_{A}+n\right)+\frac{\alpha-\gamma-\theta}{1-\alpha-\beta} \log s_{K} \\
& +\frac{\beta}{1-\alpha-\beta} \log s_{H}+\frac{\gamma}{1-\alpha-\beta} \log s_{K G}+\frac{\theta}{1-\alpha-\beta} \log s_{T R}
\end{aligned}
$$

Then the following growth equation is obtained. ${ }^{9}$

$$
\frac{d \log y}{d t}=-\lambda\left(\log y-\log y^{*}\right)+\theta\left(g_{T R}-g_{A}-n\right) t
$$

where the speed of convergence is: $\lambda=(1-\alpha-\beta+\theta)\left(\delta+g_{A}+n\right)$

By solving the differential equation, the following is obtained.

$$
\log y_{t}=e^{-\lambda t} \log y_{0}+\left(1-e^{-\lambda t}\right) \log y^{*}+\theta\left(g_{T R}-g_{A}-n\right) t
$$

which becomes:

$$
\left(\log y_{t}-\log y_{0}\right)=e^{-\lambda t} g_{A} t+\left(1-e^{-\lambda t}\right)\left(\log y^{*}-\log y_{0}\right)+\theta\left(g_{T R}-g_{A}-n\right) t
$$

where $y_{0}$ is the initial output in terms of per effective unit of labor. Dividing by $t$ and rearranging, the following equation is achieved.

\footnotetext{
${ }^{9}$ The growth equation is obtained following Mankiw, Romer, and Veil (1992).
} 


$$
\begin{aligned}
g_{y}= & (1-\theta) g_{A}+\frac{\left(1-e^{-\lambda t}\right)}{t}\left\{\log A_{0}-\frac{\alpha+\beta-\theta}{1-\alpha-\beta} \log \left(\delta+g_{A}+n\right)\right. \\
& +\frac{\alpha-\gamma-\theta}{1-\alpha-\beta} \log s_{K}+\frac{\beta}{1-\alpha-\beta} \log s_{H}+\frac{\gamma}{1-\alpha-\beta} \log s_{K G} \\
& \left.+\frac{\theta}{1-\alpha-\beta} \log s_{T R}-\log y_{0}\right\}+\theta\left(g_{T R}-n\right)
\end{aligned}
$$

where: $\quad g_{y}=\frac{\left(\log y_{t}-\log y_{0}\right)}{t}$ denotes the average rate of growth of GDP per effective unit of labor between 0 and $t$. From equation (18) we can derive a relationship between output growth and the size of the public sector. While an increase in the level of public input leads to higher growth, a smaller amount of resources are available for the accumulation of private input.

\section{AN EMPIRICAL APPLICATION TO THE ITALIAN REGIONS BETWEEN 1970 AND 1995}

We now test specific predictions of the growth model introduced in the previous section. We examine the growth effects of fiscal policy in the Italian regions during 1970-1995. The empirical investigation is carried out at two different levels. First we include all 20 Italian regions. Then the exercise is carried out for the center-southern regions in order to investigate the effect of government transfers on economic growth in the poorer part of the country.

Our data are mainly from CRENoS. These are data annual, but we followed the standard practice of taking five-year averages to remove the effects of the business cycle; we then apply panel data econometric techniques. The estimation method used is Ordinary Least Square (hereafter OLS) with dummy variables to take into account differences in the initial level of technology, $A_{0}$ and all the other differences in the steady states of the regions (Islam, 1995). In this way we get rid of the hypothesis that all regions possess similar technology and similar preferences.

In order to take into account the endogeneity problem, we consider the independent variables such as physical, human, and government capital at the start-years of the each sub-period (i.e., 1970 for 1970-1975; 1975 for 1975-1980, etc.). For the independent variable $n$, the growth rate of population, we consider a lag of five years (i.e., 1965-1970 for 1970-1975). In this case, the independent variables are predetermined with respect to the dependent variable and we use them as "instruments." In other words, we estimate a sort of reduced form by applying OLS estimators with cross-section dummy variables. 
Our regression equations follow the form of equation 18 above. As previously stressed, we initially include all Italian regions and subsequently only the centersouthern regions. We consider two different forms of panel data estimators for each regression: one-way country dummies fixed (by LSDV) and random (by GLS) effects models. Support in favor of the fixed effects model comes from the F-statistics for country effect and from the Breusch-Pagan test. Model selection is based on the Hausman test that rejects the null hypothesis of no correlation among the individual effects and the error term.

Tables 1 and 2 report the results from both models and the tests. The regression equations received support from the Durbin-Watson measure of autocorrelation, which is close to 2 for all regressions. The Lagrange Multiplier test revealed, however, the presence of heteroskedasticity. We therefore provide robust standard errors in parentheses.

Tables 1 and 2 summarize the basic results. The first column of the tables provides fixed effects estimates, while the second offers random effects estimates. We begin by discussing the conditioning variables. We find that the initial level of GDP per effective unit of labor enters the regression with a significant negative coefficient, indicating "conditional $\beta$ convergence" of growth rates in the sense of Sala-i-Martin (1996). The speed of convergence, reported in the tables, is around 0.078 for all Italian regions and 0.104 when only the center-southern regions are included. ${ }^{10}$

The neoclassical growth model predicted that if the only difference between economies lies in the level of per-worker capital stock, ${ }^{11}$ poor regions will grow faster than rich ones. Regions with lower starting values of the capital-labor ratio will have higher rates of income growth.

Central government redistribution of income from relatively rich to relatively poor regions is a channel through which convergence can occur. In Italy, until the end of the 1990 s, OSRs had basically no fiscal autonomy with the central government financing up to 95 percent of their total expenditure. These resources transferred to the regional budget have been used not only as a transfer to households but also for many different purposes by different regional governments. This raises the following policy question: have transfers helped to equalize per capita incomes across the different regions of Italy?

These transfers are assumed to be lump sum and hence do not affect relative prices or create any distortions. It is noteworthy that an increase in transfer payments reduces long-run growth through crowding out government purchases of productive goods and services. While it might be worthwhile to examine the impact of changes in

${ }^{10}$ The speed of convergence is calculated as in Sala-i-Martin (1996), as $b=\frac{\left(1-e^{-\lambda t}\right)}{t}$ with $\mathrm{t}=5$.

${ }^{11}$ Assume, following Solow (1956), that unemployment is zero. 
TABLE 1

Economic Growth in Italy (All Regions Included), 1970-1995

(Regression Results)

\begin{tabular}{|c|c|c|}
\hline \multicolumn{3}{|l|}{$\begin{array}{l}\text { Estimation Technique: Five-Year Average } \\
\text { Dependent Variable }=g_{y}\end{array}$} \\
\hline$\underline{\text { Variables }}$ & Fixed-Effects & Random-Effects \\
\hline & Coef. & Coef. \\
\hline $\log y_{0}$ & $-0.4881^{*}$ & -0.1013 \\
\hline & $(0.1566)$ & $(0.0799)$ \\
\hline $\log \left(d+g_{a}+n\right)$ & $\begin{array}{l}-0.0251 \\
(0.1799)\end{array}$ & $\begin{array}{l}-0.4023^{2 *} \\
(0.2152)\end{array}$ \\
\hline $\operatorname{Iog} S$ & 0.1387 & 0.0983 \\
\hline $\log S_{k}$ & $(0.0973)$ & $(0.0622)$ \\
\hline $\log S_{k}$ & $0.0291 * *$ & -0.0055 \\
\hline LOg $S_{k g}$ & $(0.0138)$ & $(0.0175)$ \\
\hline $\log S_{H}$ & $0.4894 * *$ & $0.2645^{* *}$ \\
\hline & $(0.2436)$ & $(0.1052)$ \\
\hline $\log S_{T r}$ & -0.0239 & -0.1970 \\
\hline $\log \mathrm{S}_{T r}$ & $(0.2995)$ & $(0.1404)$ \\
\hline & 0.1394 & $0.8954^{*}$ \\
\hline$\left(g_{T r}-n\right)$ & $(0.2342)$ & $(0.2332)$ \\
\hline $\mathrm{R}^{2}$ & 0.6147 & 0.3668 \\
\hline$\lambda$ & 0.0780 & 0.0190 \\
\hline F test that all $u \_i=0, \mathrm{~F}(19,73)$ & 3.2900 & \\
\hline (p-value) & 0.0001 & \\
\hline Durbin-Watson for fixed effects & 2.0400 & \\
\hline Breusch and Pagan test for random effects & 0.0200 & \\
\hline (p-value) & 0.8818 & \\
\hline Hausman test: $c^{2}(7)$ & 29.6600 & \\
\hline (p-value) & 0.0001 & \\
\hline
\end{tabular}

Note: (a) A constant has been included. (b) Robust standard errors are in parentheses.

(c) Number of obs: 100; Number of groups: 20; Obs. per group: 5 .

(d) $*, * *$, and $* * *$ represent, respectively, $1 \%, 5 \%$, and $10 \%$ levels of significance.

distortionary transfer payments on long-run growth, adding such distortions will only increase the negative impact of transfer payments on growth, given that they are often not productively used for investments in education, human capital, transportation, or infrastructure. The key implication of the analysis above is especially true in the centralsouthern part of Italy where the growth slowdown can be explained at least in part by the permanent increase in the ratio of government transfer payments to real GDP. Table 2, which includes only center-southern regions, shows in fact a negative relation between the rate of growth of per capita transfers, $\left(g_{T r}-n\right)$ and the dependent variable $\left(g_{y}\right)$. The elasticity of $g_{y}$ with respect to $\left(g_{T r}-n\right)$ is equal to -0.6827 . Hence a one percent increase of $\left(g_{T r}-n\right)$ leads to a decrease of 0.6827 of the growth rate of GDP. ${ }^{12}$

\footnotetext{
${ }^{12}$ The level of geographical disaggregation adopted in the estimation has a decisive influence on the magnitude of the elasticities estimated, which increase progressively as the geographical
} 
TABLE 2

Economic Growth in Center-Southern Italian Regions, 1970-1995 (Regression Results)

\begin{tabular}{|c|c|c|}
\hline \multicolumn{3}{|l|}{$\begin{array}{l}\text { Estimation Technique: Five-Year Average } \\
\text { Dependent Variable }=q_{v}\end{array}$} \\
\hline Variables & $\frac{\text { Fixed-Effects }}{\text { Coef. }}$ & $\frac{\text { Random-Effects }}{\text { Coef. }}$ \\
\hline $\log y_{0}$ & $\begin{array}{l}-0.6806^{*} \\
(0.1425)\end{array}$ & $\begin{array}{l}-0.0431 \\
(0.0644)\end{array}$ \\
\hline $\log \left(d+g_{a}+n\right)$ & $\begin{array}{l}-0.7175^{*} \\
(0.1798)\end{array}$ & $\begin{array}{l}-0.6915^{* *} \\
(0.2195)\end{array}$ \\
\hline $\log S_{k}$ & $\begin{array}{c}0.0459 \\
(0.0676)\end{array}$ & $\begin{array}{c}0.0006 \\
(0.0534)\end{array}$ \\
\hline $\log S_{k g}$ & $\begin{array}{l}0.0457 * * \\
(0.0189)\end{array}$ & $\begin{array}{c}0.0256 \\
(0.0194)\end{array}$ \\
\hline $\log S_{H}$ & $\begin{array}{l}0.0975 \\
(0.1044)\end{array}$ & $\begin{array}{c}0.0513 \\
(0.1089)\end{array}$ \\
\hline $\log S_{T r}$ & $\begin{array}{l}0.3405^{* * *} \\
(0.2069)\end{array}$ & $\begin{array}{l}-0.1957 \\
(0.1398)\end{array}$ \\
\hline$\left(g_{T r}-n\right)$ & $\begin{array}{l}-0.0507 \\
(0.2310)\end{array}$ & $\begin{array}{r}0.7699^{*} \\
(0.2323)\end{array}$ \\
\hline $\mathrm{R}^{2}$ & 0.7943 & 0.4856 \\
\hline$\lambda$ & 0.1040 & 0.0090 \\
\hline $\begin{array}{l}\mathrm{F} \text { test that all } u \_i=0, \mathrm{~F}(11,41) \\
(\mathrm{p} \text {-value })\end{array}$ & $\begin{array}{l}5.600 \\
0.0000\end{array}$ & \\
\hline Durbin-Watson for fixed effects & 2.1110 & \\
\hline $\begin{array}{l}\text { Breusch and Pagan test for random effects } \\
\text { (p-value) }\end{array}$ & $\begin{array}{l}0.0500 \\
0.8298\end{array}$ & \\
\hline $\begin{array}{l}\text { Hausman test: } c^{2}(7) \\
\quad(p \text {-value })\end{array}$ & $\begin{array}{r}32.4400 \\
0.0000\end{array}$ & \\
\hline
\end{tabular}

Note: (a) A constant has been included. (b) Robust standard errors are in parentheses.

(c) Number of obs: 60; Number of groups: 12; Obs. per group: 5 .

(d) $*, * *$, and $* * *$ represent, respectively, $1 \%, 5 \%$, and $10 \%$ levels of significance.

Hubbard, Skinner, and Zeldes (1995) find that social assistance discourages saving because it is usually conditional on the individual not having any assets. ${ }^{13}$ Another perhaps more speculative mechanism worthy of attention is that the potential profit from

focus narrowed. The elasticity of the growth rate of GDP with respect to variable government transfers $(g t r-n)$ is given by the estimated coefficient $(-0.051)$ times the ratio of the sample means of GDP and government transfers. The sample means of GDP and transfers are, respectively, 10.2542 and 9.0925

${ }^{13}$ Other studies find negative effects on precautionary saving of more generous unemployment insurance. See, for example, Engen and Gruber (1996). 
rent-seeking may expand as the public sector grows, which may lead to a greater diversion of resources into unproductive uses (Buchanan, 1980). ${ }^{14}$

It is noteworthy that two key roles of government are to provide public goods and to redistribute income across individuals and regions. Often these two functions overlap since the public goods provisions may also be used to compensate for geographical income imbalances in Italy, where the economy in the south is overly dependent on welfare instruments and government resources. As a consequence, the resources left over for productive investment are diminished as transfers expand.

But if this government policy results in a decline in output growth in the centersouthern regions, why is this redistributive system chosen? Over time the south is caught in an equilibrium of dependency in which social assistance and public jobs ${ }^{15}$ which in the south are of the nature of permanent welfare ${ }^{16}$ - are critical sources of disposable income and in which private opportunities do not materialize. This creates a culture that discourages private activities and entrepreneurship and does not enhance growth investments.

We present evidence showing that when we restrict our sample to only centersouthern Italian regions, the rate of growth of government transfers is negatively correlated with economic growth. However, when all Italian regions are taken into account, the coefficient changes sign.

In a recent review article, Agell, Lindh, and Ohlsson (1997) claim that theoretical and empirical evidence does not allow any conclusion as to whether there is a relationship between the rate of economic growth and the size of the public sector. Fölster and Henrekson (1999) extend the Agell, Lindh, and Ohlsson (1997) review to highlight some problems with their analysis. They present evidence showing that once a

\footnotetext{
${ }_{14}$ See Nitzan, Gradstein, and Slutsky (1994) for a recent review of the rent-seeking literature.

${ }^{15}$ A model by Coate and Morris (1995), slightly modified by Alesina, Baqir, and Easterly (2000), clarifies this political-economic argument. The idea is simple: suppose that a proposal that introduces a tax in region 1 (north) to finance a direct subsidy to region 2 (south) does not pass because it is opposed by voters in the north. Further assume that the government wants to redistribute toward the south and assume that, say, several new teachers are hired and disproportionately placed in the south. This second redistributive policy is less transparent (although perhaps less efficient) and may win approval even in the north because of the uncertainty about the real needs of the public school system.

${ }^{16}$ The regional differences in the distribution of public jobs are large. Public civilian employment per capita is higher in the south than in the north (about 61 public employees per thousand population in the south versus 51 in the north). As a share of total employment, the difference is even more staggering: 12 percent of the employed in the north are in the public sector against 21 percent in the south. The comparison with the center is clouded by the presence of the national capital in the Lazio region. Including this region, public employment is artificially high in the center. For this reason we focus mostly on north-south comparisons.
} 
number of econometric issues are dealt with, the relationship between growth and public expenditures may be more robustly negative than it first appears.

In Table 1, the rate of growth of per capita government transfers, $\left(g_{T r}-n\right)$ has a positive sign. This sign results from the regression that includes also the northern and richer regions. The elasticity of the dependent variable $\left(g_{y}\right)$ with respect to the independent variable is equal to $0.1229 .{ }^{17}$ If $\left(g_{T r}-n\right)$ increases by 1 percent, the growth rate of GDP increases by 0.1229 percent. The different sign of the variable in Tables 1 and 2 is a notable feature of the results. Given recent developments in growth theory, it is intriguing to speculate that government transfers may actually help rather than hinder economic growth. Table 1 presents some suggestive cross-regional evidence indicating that the relationship between the rate of growth of social transfers and growth in transition economies has in fact been positive, which is similar to Perotti's (1996) finding for a different and larger sample of countries. He supports the view that redistribution can enhance growth by fostering sociopolitical stability. Economic growth in fact is largely determined by the accumulation of capital, human capital, and knowledge usable in production. The incentives for such productive accumulation hinge on the ability of individuals to appropriate privately the fruits of their efforts, which in turn crucially hinges on what tax policies and regulatory policies are adopted.

Another interesting case, from our prospective, is represented by the variable $\left(S_{K G}\right)$. The estimated coefficient $\left(\log S_{K G}\right)$ is greater when we consider only the center-southern regions (Table 2) since capital productivity is higher in the less developed regions. Public physical capital spending is a direct channel by which fiscal policy can affect national investment and national productivity growth. A large empirical literature surveyed by Gramlich (1994) suggests that an increase in infrastructure spending stimulates growth. ${ }^{18}$ It has been recognized that the public infrastructure - streets and highways, mass transit, water and sewer systems, and the like - should be considered as a factor of production along with labor and private capital in the private sector production process. These results suggest that cross-region differences in productivity growth might also be explained partly by differences in levels of public physical capital spending.

Closely related to the variable $\left(S_{K G}\right)$ is the other relevant variable, private physical capital investment $\left(S_{k}\right)$, which has a low positive effect on economic growth. With respect to this variable $\left(S_{k}\right)$, we found a relatively positive stronger effect on economic growth when we consider the first environment that includes all Italian regions (Table 1). This can be explained by the fact that when we include the northern Italian regions,

\footnotetext{
${ }^{17}$ The sample means of GDP and transfers are, respectively, 10.4075 and 9.01859 .

${ }^{18}$ Although several empirical studies using cross-national data sets (e.g., Landau 1983; Kormendi and Meguire 1985; and Barro 1991b) found a negative or statistically insignificant relationship between government purchases and growth, the theoretical and empirical analyses above suggest reexamining these results by holding the total government spending ratio constant.
} 
we take into account those regions that are characterized by a greater number of entrepreneurs with an higher propensity to invest.

The variable $\left(S_{H}\right)$ proxies the role of human capital in enhancing growth; it has a significant positive effect, as expected. The coefficient is greater and statistically significant when we consider all Italian regions (Table 1) due to the fact that, as pointed out by Barro (2001), "more human capital facilitates the absorption of superior technologies from leading" regions. Finally, the rate of population growth $(n)$, augmented with the rates of depreciation $(\delta)$ and rate of technical progress $\left(g_{A}\right)$, is statistically significant and negatively related with the dependent variable.

\section{CONCLUSION}

One main question has dominated discussions of recent economic policy: assuming that economic growth is desirable for its own sake, what can be done to increase its average rate? This article addresses this question with respect to Italy and appears to point in two distinct directions. This is because the northern regions show an aboveaverage concentration of infrastructure and funds, ultimately reflecting the historical pattern of industrialization, while the opposite situation characterizes the traditionally agricultural regions in the south.

The question then becomes, what can be done to increase the average rate of economic growth in the center-southern part of Italy? If policy makers are serious about increasing the average rate of economic growth, they will have to think in terms of substantial increases in government purchases relative to GNP. We found that the amount of resources that are transferred to the regional budget in order to achieve a more equalized distribution of revenues do not always enter as productive inputs in private production functions. These public resources may be unproductive in that they do not raise the marginal product of private capital, especially when the analysis is restricted to the central-southern regions. An explanation may be that these resources are mainly used as redistributive devices, while the large empirical literature surveyed by Gramlich (1994) suggests that policy makers should concentrate their efforts on increases in infrastructure spending if they aim to implement policies with a maximum impact on growth. These increases in government purchases could be financed by decreases in transfer payments and not by increases in tax rates.

Another important contribution of the model tested is to highlight the rivalrous nature of the public capital stock and of public transfer payments. This approach overcomes the need in earlier models of growth and public finance (such as Barro (1990)) for the goods provided by government to be essentially publicly provided private goods. The present model implies that many of the goods provided by government are rivalrous and nonexcludable in nature, which helps to explain the lack of a strong impact of public spending on growth, especially when we consider all Italian regions. 
In addition to estimating the empirical relationship among public investment, transfers, and the rate of economic growth, we improve on previous empirical studies of the influence of fiscal policies on growth that predominantly concentrated on the effects of government consumption spending and largely ignored the effects of government transfers. By using a panel data framework, this paper goes beyond the traditional empirical tests found in this literature, which most often use cross-sectional estimation alone. Levine and Renelt $(1991,1992)$ and Levine and Zervos (1993) point out that such crosssectional studies are prone to yield misleading results, given that they cannot account for persistent unobserved heterogeneity across regions.

\section{APPENDIX: DEFINITIONS AND DATA SOURCES}

Our data come mainly from the CRENoS database. We have used annual data for the period 1970-1995. The variables included in the tables are defined as follows.

$$
\begin{aligned}
& g_{y}=\text { rate of growth per working-age GDP at prices } 1990 \text { for each sub-period } \\
& \text { (source: authors' elaboration from CRENoS data). } \\
& y_{0}=\text { initial value of per working-age person GDP at prices } 1990 \text { for the first year } \\
& \text { of every time span (source: CRENoS). } \\
& \delta=\text { depreciation rate, equal to } 11.0 \text { per cent (source: ISTAT). } \\
& n=\text { annual average of the rate of growth of working-age population for each } \\
& \text { sub-period (source: authors' elaboration from CRENoS data). } \\
& g_{A}=\text { rate of technical progress, equal to } 2 \text { percent as in Mankiw, Romer, and } \\
& \text { Weil (1992). } \\
& S_{K}=\text { annual average of share of private physical capital investment in total GDP } \\
& \text { for each sub-period (source: authors' elaboration from CRENoS data). } \\
& S_{K G}=\text { annual average of share of public physical capital investment in total GDP } \\
& \text { for each sub-period (source: authors' elaboration from Prometeia). }
\end{aligned}
$$




\section{REFERENCES}

Agell, J., T. Lindh, and H. Ohlsson, 1997. "Growth and the Public Sector: A Critical Review Essay," European Journal of Political Economy 13(1), 33-52.

Alesina, A. and D. Rodrik, 1994. "Distributive Politics and Economic Growth," Quarterly Journal of Economics 109(2), 465-90.

Alesina, A., R. Baqir, and W. Easterly, 2000. "Redistributive Public Employment," Journal of Urban Economics 48, 219-41.

Armstrong, H. and R. Vickerman, 1995. Convergence and Divergence Among European Regions. Pion: London.

Arrow, K.J. and M. Kurz, 1970. Public Investment, the Rate of Return, and Optimal Fiscal Policy. Resources for the Future Inc. and Johns Hopkins Press: Baltimore, MD.

Aschauer, D.A., 1988. "The Equilibrium Approach to Fiscal Policy," Journal of Money, Credit, and Banking 20, 41-62.

Bajo, O., D.R. Carmen, and M.D. Montavez, 1999. "Fiscal Policy and Economic Growth: The Case of Spanish Regions," ftp://ftp.econ.unavarra.es/pub/ DocumentosTrab/DT9904.pdf.

Barro, R.J., 1990. "Government Spending in a Simple Model of Endogenous Growth," Journal of Political Economy 98(5), 103-125. , 1991a. "A Cross-Country Study of Growth, Saving, and Government Growth," in B.D. Beraheim and J.B. Shoven (eds.), National Saving and Economic Performance. University of Chicago Press: Chicago, IL, 269-301. , 1991b. "Economic Growth in a Cross Section of Countries," Quarterly Journal of Economics, 407-44. , 1992. "Human Capital and Economic Growth," Policy for Long-Run Economic Growth, Federal Reserve Bank: Kansas City, 199-216. , 2001. "Human Capital and Growth," American Economic Review 91(2), 12-17.

Barro, R.J and X. Sala-i-Martin, 1992a. "Public Finance in Models of Economic Growth," Review of Economic Studies 59, 645-61. , 1992b. "Convergence," Journal of Political Economy 100(2), 223-51. 1995. Economic Growth. McGraw-Hill: New York.

Baxter, M., and R.G. King, 1993. "Fiscal Policy in General Equilibrium," American Economic Review 83, 315-34.

Benabou, R. 1993. "Workings of a City: Location, Education, and Production," Quarterly Journal of Economics 108(3), 619-52

, 1994. "Education, Income Distribution and Growth: The Local Connection," Economic and Financial Review 1(4), 247-48

, 1996. "Inequality and Growth" in NBER Macroeconomics Annual, B.S Bernanke. and J. J. Rotemberg (eds.). MIT Press: Cambridge, MA, 11-74.

Bertola, G., 1993. "Models of Economic Integration and Localized Growth" in: Adjustment and Growth in the European Monetary Union, F. Torres and F. Giavazzi (eds.). Cambridge University Press: Cambridge, 159-79. 
Auteri/Costantini: Fiscal Policy and Economic Growth: The Case of the Italian Region

Cashin, P., 1995. "Economic Growth and Convergence Across the Seven Colonies of Australasia, 1861-1991," Economic Record 71, 128-40.

Center for North South Economic Research (CRENoS), Italian regions, http://www.crenos. unica.it

Cheshire, P. and G. Carbonaro, 1995. "Convergence and Divergence in Regional Growth Rates: An Empty Black Box?," in H. Armstrong and R. Vickerman (eds.), Convergence and Divergence among European Regions. Pion: London, $89-111$.

Coate, S. and S. Morris, 1995. "On the Form of Transfers to Special Interests," Journal of Political Economy 103, 1210-35.

Devarajan, S., V Swaroop, and H. Zou, 1996. "The Composition of Public Expenditures and Economic Growth," Journal of Monetary Economics 37(2), 313-344.

Domar, E., 1946. "Capital Expansion, Rate of Growth and Employment," Econometrica $14,137-47$. 1947. "Expansion and Employment," American Economic Review 37(1), 343-55.

Easterly, W. and S. Rebelo, 1993. "Fiscal Policy and Economic Growth," Journal of Monetary Economics 32, 417-58.

Engen, E. and J. Gruber, 1996. "Unemployment Insurance and Precautionary Savings," National Bureau of Economic Research Working Paper 5252, Cambridge, MA.

Feldstein, M., 1974. "Incidence of a Capital Income Tax in a Growing Economy with Variable Savings Rates," Review of Economic Studies 41, 505-13.

Fölster, S. and M. Henrekson, (1999). "Growth and the Public Sector: A Critique of the Critique," European Journal of Political Economy 15, 337-358.

Futugami, K., Y. Morita, and A. Shibata, 1993. "Dynamic Analysis of and Endogenous Growth Model with Public Capital," Scandinavian Journal of Economi, 95, 60725.

Gramlich, E.M., 1994. "Infrastructure Investment: A Review Essay," Journal of Economic Literature 32, 1176-96.

Grossman, G.M., and E. Helpman, 1991. Innovation and Growth in the Global Economy. MIT Press: London.

Harrod, R.F., 1939. “An Essay in Dynamic Theory,” Economic Journal, 49, 14-33. 1948. Toward a Dynamic Economies. London: Macmillan.

Hubbard, G.R., J. Skinner, and S.P. Zeldes, 1995. "Precautionary Saving and Social Insurance," Journal of Political Economy 103, 360-99.

Islam, N., 1995. "Growth Empirics: A Panel Data Approach," Quarterly Journal of Economics 60, 1128-70.

Istituto Nazionale di Statistica (Istat), http://www.istat.it.

Jayaratne, J. and P.E. Strahan, 1996. "The Finance-Growth Nexus: Evidence from Bank Branch Deregulation," The Quarterly Journal of Economics 111, 639-70.

Jones, L.E., R.E Manuelli, and P.E. Rossi, 1993. "Optimal Taxation in Models of Endogenous Growth," Journal of Political Economy 101, 485-517.

Judd, K., 1985. "Short-Run Analysis of Fiscal Policy in a Simple Perfect Foresight Model," Journal of Political Economy 93(2), 298-319. 
King, R.G and S. Rebelo, 1990. "Public Policy and Economic Growth: Developing Neoclassical Implications," Journal of Political Economy 98(5), 126-50.

Kormendi, R.C. and P.G. Meguire, 1985. "Macroeconomic Determinants of Growth: Cross-Country Evidence," Journal of Monetary Economics 16, 141-63.

Krueger, A.O., 1974. "The Political Economy of the Rent Seeking Society," American Economic Review 64, 291-303.

Kryzaniak, M., 1967. "The Long-Run Burden of a General Tax on Profits in Neoclassical World," Public Finance 22, 472-91.

Landau, D., 1983. "Government Expenditure and Economic Growth: A Cross-Country Study," Southern Economic Journal 49(3), 783-792.

Levine, R., 1991. "Stock Markets, Growth, and Tax Policy," Journal of Finance 46(4), 1445-65.

Levine, R. and D. Renelt, 1991. "Cross-Country Studies of Growth and Policy: Methodological, Conceptual and Statistical Problems," World Bank Policy Research and External Affairs Working Paper 608. World Bank: Washington. , 1992. "A Sensitivity Analysis of Cross-Country Growth Regressions," American Economic Review 82, 942-63.

Levine, R. and S. J. Zervos, 1993. "What Have We Learned About Policy and Growth from Cross-Country Regressions?" American Economic Review 83, 426-30.

Lucas, R.E. Jr., 1988. "On the Mechanics of Economic Development," Journal of Monetary Economics, 22, 3-42.

Lucas, R.J., 1990. "Government Spending in a Simple Model of Endogenous Growth," Journal of Political Economy 98(5), 103-26

Mankiw, N.G., D. Romer, and D.N. Weil, 1992. "A Contribution to the Empirics of Economic Growth," Quarterly Journal of Economics 107(2), 407-37.

Mendoza, E., G. Milesi-Ferretti, and P. Asea, 1997. "On the Ineffectiveness of Tax Policy in Altering Long-Run Growth: Harberger's Auperneutrality Conjecture,". Journal of Public Economics 66, 99-126.

Miller, S.M. and F.S. Russek, 1997a, "Fiscal Structures and Economic Growth: International Evidence," Economic Inquiry 35(3), 603-613. , 1997b, "Fiscal Structures and Economic Growth at the State and Local Level," Public Finance Review 25(2), 213-37.

Nitzan, S., H.M. Gradstein, and S. Slutsky, 1994 "Uncertainty, Information and the Private Provision of Public Goods," European Journal of Political Economy 10, 449-464.

Padovano F. and E. Galli, 2001. "Tax Rates and Economic Growth in the OECD Countries (1950-1990)," Economic Inquiry 39(1), 44-57.

Perotti, R., 1996. "Growth, Income Distribution, and Democracy: What the Data Say," Journal of Economic Growth 1(2),. 149-187.

Prometeia, Osservatorio congiunturale o di scenari per le economie, http://www.prometeia.it.

Razzolini, L. and W.F. Shughart II, 1997. "On The (Relative) Unimportance of a Balanced Budget," Public Choice 90, 215-33.

Rebelo, S., 1991. "Long Run Policy Analysis and Long Run Growth," Journal of Political Economy 99, 500-521. 
Romer, P.M, 1986. "Increasing Returns and Long-Run Growth," Journal of Political Economy 94, 1002-37. , 1989a. "Capital Accumulation in the Theory of Long Run Growth" in R.J. Barro (ed), Modern Business Cycle Theory. Harvard University Press: Cambridge, MA, 51-127.

, 1989b. "Human Capital and Growth: Theory and Evidence," National Bureau of Economic Research Working Paper 3173. Cambridge, MA.

, 1990a. "Capital, Labor, and Productivity," Brookings Papers on Economic Activity, Special Issue, 0 (0), 337-420.

, 1990b. "Endogenous Technical Change," Journal of Political Economy 98(5), 71-102.

, 1994. "The Origins of Endogenous Growth," Journal of Economic Perspectives, 8(1), 3-22.

Sala-i-Martin, X., 1991. "The Classical Approach to Convergence Analysis," Economic Journal 106, 1019-36.

, 1996. "Regional Cohesion: Evidence and Theories of Regional Growth and Convergence," European Economic Review 40,1325-52.

, 1997. "Transfers, Social Safety Nets, and Growth," IMF Staff Papers 44 (1), 81102.

Sato, K., 1967. "Taxation and Neoclassical Growth," Public Finance 22, 346-370.

Shell, K., 1967. "A Model of Inventive Activity and Capital Accumulation," in K. Shell (ed.) Essays on the Theory of Optimal Economic Growth. MIT Press: Cambridge, MA, 67-85.

Solow, R., 1956. "A Contribution to the Theory of Economic Growth," Quarterly Journal of Economics 70, 65-94.

Srinivasan, T.N., 1995. "Long-Run Growth Theories and Empirics: Anything New" in I. Takatoshi. and A.O. Krueger (eds), Growth Theories in the Light of East Asian Experience. , University of Chicago Press: Chicago, 37-70.

Stokey, N.L. and S. Rebelo, 1995. "Growth Effects of Flat-Rate Taxes," Journal of Political Economy 103(3) 519-50.

Swan, T.W., 1956. "Economic Growth and Capital Accumulation," Economic Record $32,334-61$.

Thompson, E.A, 1974. "Taxation and National Defense," Journal of Political Economy, July/August, 755-782.

Trostel, P.A., 1993. "The Effect of Taxation on Human Capital," Journal of Political Economy 101, 327-50.

Turnovsky, S.J., 1996. "Optimal Tax, Debt, and Expenditure Policies in a Growing Economy," Journal of Public Economics 60(1), 21-44.

Turnovsky, S.J and W.H. Fisher, 1995. "The Composition of Government Expenditure and its Consequences for Macroeconomic Performance," Journal of Economic Dynamics and Control 19, 747-86. 